\title{
AMERICAN PERSPECTIVES ON SUICIDALITY AMONG MEN IN POLAND
}

\author{
JAROSŁAW R. ROMANIUK ${ }^{1}$, ANNA KOTLARSKA-MICHALSKA ${ }^{2}$, \& KATHLEEN J. \\ FARKAS ${ }^{3}$ \\ ${ }^{1}$ Case Western Reserve University, Jack, Joseph and Morton Mandel School of Applied Social Sciences, \\ 11235 Bellflower Road, Cleveland, Ohio 44106, USA. ORCID: 0000-0002-8568-6587, Email: jrr3@case. \\ $\underline{\text { edu }}$ \\ ${ }^{2}$ Adam Mickiewicz University, Szamarzewskiego,89c, 60-568 Poznań, Poland. ORCID: 0000-0002-2486- \\ 4984, Email: anna_michalska@poczta.onet.pl \\ ${ }^{3}$ Case Western Reserve University, Jack, Joseph and Morton Mandel School of Applied Social Sciences, \\ 11235 Bellflower Road, Cleveland, Ohio 4106, USA. ORCID: 0000-0002-1937-3603, Email: kjf@case.edu
}

ABSTRACT: This article examines sociological, psychological, and suicidological research on the determinants of male suicide to explore the fact that Polish men complete suicide 7.4 times more than women, a frequency twice as high as in the US. This paper is based upon an examination of relevant literature and statistical databases. A keyword search was completed in both Polish and English language databases. Ideals of masculinity and negative social attitudes towards a non-binary view of gender may increase stressors and discourage men in Poland from revealing their problems while seeking support, explaining the high rates of suicide completion among Polish men. Suicide prevention programs must tackle gender conceptualizations and alcohol use patterns as well as increase avenues for male help-seeking behaviors. These changes will require political and religious organizations to confront the weakening of male hegemony as the organizing principle for family and society. This paper explores the increased rate of male suicide in Poland from the perspective of gender.

KEYWORDS: gender, masculinity, social work, sexual minorities, alcoholism, identity formation, suicide prevention 


\section{INTRODUCTION}

Suicide is a result of many factors and often difficult to predict (Hołyst 2002; Rodziński et al. 2017; Czabański \& Mariański 2018). Psychologists and psychiatrists study suicidal behavior as a mental health problem among individuals. However, suicide is also widely thought to have sociological explanations leading to differences in the prevalence of suicidal behaviors in various countries and cultures (Chu et al. 2010). In this paper we ask questions concerning the personal and socioeconomic conditions that may prevent or enable suicide for specific populations in Poland and make comparisons with conditions in the United States.

The most startling finding from a review of suicide statistics across countries and cultures concerns the gender difference in the frequency of suicide. The ratio of suicide occurrence (RSO) among men can be several times higher than for women (Richie et al. 2020). According to OurWorldInData.org (Richie et al. 2020), the proportion of men to women (RSO) in the United States is 3.5; that is, men in the US completed suicide 3.5 times more than women. ${ }^{1}$

In Poland, the RSO is more dramatic; Polish men complete suicide 7.4 times more than women, a frequency twice as high as in the US. The Polish RSO is one of the highest in the entire world, and, to date, there is not much explanation for it. In Poland and the US, the significant difference in the suicide ratio between men and women has not changed for decades (Ritchie et al. 2020). Very little empirical research is dedicated to exploring the causality of the significantly higher suicide completion rates among men than women, but some hypotheses concern higher levels of access to services among women and the use of less lethal means by women (Coleman 2015). The work of Höfer et al. (2012) suggested that women in Poland use "soft" methods to kill themselves, such as poisoning, whereas men use hanging. The discrepancy in suicide occurrence among men and women could also be the result of less formal documentation of suicide when "soft" methods are used.

Understanding the difference in male to women suicide occurrence is essential for the planning of any prevention strategies. According to Sobkowiak's (2011) guide to suicide prevention, the best approach is public education about the causes and symptoms of suicidal behavior. Two questions are of fundamental significance: 1 . Why, in

\footnotetext{
${ }^{1}$ This paper used OurWorldInData.org data (Ritchie et al. 2020) concerning suicide ratios as they show change (or a lack of change) over an extended period of time. However, research conducted at another time or with other methods may produce different data (Rosa 2012). Although the exact numbers can be different, the significance of the differences in the data for men and women in the countries discussed is still valid. This perspective changes when we compare data from other countries and other cultures. For example, in China the ratio of male to female suicide ratio is about 1.5. It is tempting to explain this result by the long-lasting tradition of the absence of a male and female polarity in Chinese culture (Wang 2005), but in today's reality there might be different considerations. The authors do not exclude the existence of other sources of the differences in RSO discussed here, but we did not find any other competing explanation besides those cited in this work. Perhaps more international studies could offer more insight explaining why the male to female ratio in suicide can be so different (from about 1.5 in China to above 7 in eastern European countries) across different countries and different cultures (Richie et al. 2020).
} 
some cultures, such as the United States and Poland, do men complete suicide more often than women? and 2. Why is this ratio (RSO) twice as high in Poland than in the US? Since these differences concern a phenomenon related to gender, we look for an explanation in issues related to gender. There are many factors that may explain the etiology of suicide in relation to gender, but we will focus on two hypotheses we found in the literature to be the most general and that can be verified across cultures and time. The first pertains to the meaning that society gives to each gender (Payne et al. 2008; Coleman 2015), and the second concerns the culture of alcohol consumption (Landberg 2008; Razvodovsky 2015). The authors of this paper are social workers with interests in international social work and a focus on comparing sociological incidences in Poland and the US (Kotlarska-Michalska 2019a). Throughout our years of cooperation with social workers in Poland and the US, we encountered both similarities and differences in the approach to gender issues and addiction.

\section{METHOD}

This paper is based upon a review of relevant literature and statistical databases. A keyword search was completed using the following key words: gender, suicide, suicide risk, suicide prevention, masculinity and variations of these words. Databases include both English and Polish language articles published within the past fifteen years. Classic sociological and psychological literature was included because of its topical relevance. Both empirical studies as well as theory-based articles were included in the literature review. Papers published in the Polish language were translated into English by the primary author, and the translations reviewed by a native English speaker fluent in Polish. It needs to be stressed that our goal was not a literature review concerning suicide and masculinity but the search for the answer to why men in Poland complete suicide seven times more often than women whereas the same ratio in the US is 3:5. This is why our main focus was on gender differences concerning suicidal behavior.

\section{BACKGROUND THEORY}

In an effort to design appropriate techniques for prevention, we will begin with a focus on the bio-psychosocial basis of suicide and then explain its gender associated etiology, with special reference to the incidence of suicide in Poland and the United States. Psychological explanations for suicide such as the theory of needs and the theory of alienation provide a starting point for analysis, but these theories do not answer the question of why a person attempts suicide. The sociological point of view initiated by Durkheim (1897/1951) is still being developed and can be treated as parallel to the psychological trend. Some studies have confirmed the importance of additional factors that were not included in Durkheim's studies. A Dublin and Bunzel (1933) study confirmed the influence of gender and community values on suicide attempts, showing that the suicide rate among foreign men was twice as high as for the entire male population in the USA.

One of the theories on which social workers build their practice is Erikson's epige- 
netic concepts of bio-psycho-social development (Gibson 2007). According to Erikson, both men and women face different crises specific to the age of development during their lives. At a young age the developmental task is achieving a healthy identity. In middle age, individuals are expected to be productive and creative, applying acquired skills and resources; in later years, they are supposed to achieve satisfaction from their life accomplishments. Erikson's ideas can be applied to an initial understanding of the higher rates of suicide among men. In both the US and in Poland, the expectation is for men to be self-reliant, independent, and financially successful (Pirkis et al. 2017). For women, there are a number of different ways to be successful, but for men, the path of success is narrower and always includes economic stability. Men who do not meet their developmental goals may feel lost, unaccomplished, and less than others. Each developmental crisis, when not resolved, may generate a state of hopelessness and despair that could then lead to suicide.

Erikson's theory is very helpful when considering the research of Shiner and coworkers (2009) on men's suicide across the lifespan. Today's young men can be confused by societal messages questioning traditional masculinity and the model of male identity. The world of middle-aged men has been shaken by changes in the globalized work market, transformations of the family model, and women's empowerment both in and out of the family setting (Möller-Leimkühler 2003). In recent decades, the man's role as the main breadwinner is questioned at the same time that social support for his difficulties is diminishing. Elderly men experience physical problems and losses due to aging processes, which might be detrimental to their sense of their life accomplishments. They might increase their alcohol consumption, thereby reinforcing their health problems (Möller-Leimkühler 2003; Binczycka-Anholcer 2005). All of these crises can be viewed within the context of the ideal of masculinity. When the developmentally appropriate masculine ideal becomes difficult to reach, a man reaches a crisis.

\section{HEGEMONIC MASCULINITY}

The concept of hegemonic masculinity attempts to describe the position of men in today's society. The adjective hegemonic defines this position as one of dominance and power. We understand that the standing of men in society is different in various moments of our history and that this standing changes with the political and economic system that places men in hierarchical construct (Connell 2002). Poland and the US belong to countries with a patriarchal culture, where men are awarded a higher social status than women. However, not all men share the same status. The highest, ideal status, especially when talking about the US, belongs to a white heterosexual man, married with children, employed, and educated. In Poland, being of the Roman Catholic faith also adds to a man's social status. In other words, married, heterosexual men with children have more social privileges than unmarried, gay, or divorced men. The ideal representation of a man is a patriotic man expressing the nationalist ethos (Barłowski 2018). In Poland, he is Catholic, married with children, able to serve in the military, and educated and employed. Sometimes, the professional or social position 
is high enough to replace other attributes. For example, Polish Catholic priests are not married and are childless, but they occupy a high position in society as a result of their profession and the country's long relationship with the Roman Catholic Church.

Most adult Poles declare that they belong to the Catholic Church and the Church ideology regarding a "real" man may create pressure on men, thereby increasing men's stress. However, the lack of information in the Polish police statistics on the attitude towards religion among those who have completed suicide does not allow us to confirm the relationship between religiosity and suicide. The possibility that religion, including the Catholic religion, could be a protective factor against suicide in the US was also discussed (Norko et al. 2017).

Some authors discuss hegemonic masculinity in terms of masculine domination (Reddy et al. 2019), a discussion that is very close to the discourse on social privileges. The ideal of masculinity defines not only the goal for individual males to achieve, but also creates a hierarchy of men from the most successful to the least desirable subpopulation of men. A man on the top of the masculine hierarchy would be accomplished in an area of work, physically fit, stoic, and a member of a social majority group defined by such characteristics as religion, race, and sexual orientation. On the other end of the masculine social hierarchy are men representing minority groups who are not successful and have some missing attributes of this idealized masculinity. Following this theory, men with a different skin color, different religion than the mainstream, who are unemployed and/or poor, homeless, and physically or mentally disabled will live their lives experiencing different forms of social exclusion, stigma, and discrimination in part based upon their failure to attain the elements of the ideal masculine stereotype.

There is a discussion in the literature concerning the use of the term masculinity vs toxic masculinity (de Boise 2019). In our work we will use the term masculinity as it was used in our literature sources. We understand, however, that when using this term in the context of suicide, the term "toxic" seems appropriate. The term masculinity is general and possibly misleading when analyzing how stereotypical male behavior has changed in recent decades (de Boise 2019).

People generally assume that biology determines sex, who is male and who is not. Although humanities scholars have already stopped using a binary description of gender (Bieńkowska 2011), the public continues to argue about what we have learned from biology (Hamidi \& Nippoldt 2019). Recent progress in genetics has brought new data to the discussion concerning sex and gender. It has been suggested that there is no one single type of genes for male and female sex. Each human may have a different group of genes that can be placed on the X or Y chromosome, affecting sexuality. There is no such thing as a definitive gene package for hegemonic masculinity (Snell et al. 2018). Progress in epigenetics may verify new ways in which environment can affect people's sexuality and create generational changes in human behavior (Fine et al. 2017; Cortes et al. 2019). 


\section{GENDER DIFFERENCES IN SUICIDALITY}

In western literature there is a long tradition of forming theories of masculinity that are defined in opposition to femininity (Connell 2002). However, their application in understanding the gender difference in suicide is limited (Pirkis et al. 2017). In Poland, the discussion concerning hegemonic masculinity is less complete in comparison with western countries (Kluczyńska 2018), partially due to a limited interest in "gender studies" and due to significant criticism from conservative activists and government leaders (Odrowąż-Coates 2015; Korolczuk 2020). Nevertheless, most of the research cited in this work discusses the role of hegemonic masculinity in creating the social pressure among men to conform to this ideal of masculinity. Our paper then is not just another voice in the discussion about the concept of masculinity or masculinities, but an exploration of how the ultimate goal of "being a man" may lead to individual and perceived societal pressures that affect an individual's decision to kill himself (Möller-Leimkühler 2003; Payne et al. 2008; Coleman 2015; Coleman et al. 2020) and how those societal stresses differ between Poland and the US.

Suicide Completion: The research of Maria Jarosz provides information on the influence of gender on completing suicide. Jarosz hypothesizes that the position of the Polish woman has long been relatively high, related to the woman's special role of cultivating and transmitting patriotic and religious values (Jarosz 2004). Jarosz claims that the high position of the woman in the family and society may be, for a man, a factor that is both stressful and suicidogenic. Those cultural determinants that influence low rates of female suicide death result in a dangerous self-destructive syndrome for men, resulting in a higher suicide rate for men (Jarosz 2004).

Loss of Love: Among men who attempt suicide, about half of them die; among women, the rate is less than one-third (Hołyst 2002). Hołyst rightly reminds us that the key factor playing a role in the etiology of suicides is the state of satisfying needs and the disruption of interpersonal bonds. He points out that the syndrome of pathologizing interpersonal bonds is defined as the loss of love syndrome (Hołyst 2002). At this point, we can ask whether the lack of love is a more difficult blow for men to accept, since this factor plays such an important role in making the decision for suicide. It is difficult to answer this question because this factor is not included in suicidological studies.

Reasons for Suicide: Research conducted in 2000 by the Polish Society of Mental Hygiene under the supervision of Hołyst, on a nationwide sample, showed that Poles who are in the worst financial situation have suicidal tendencies. This percentage is seven times higher than in people who have a different financial situation. A more frequent occurrence of suicidal intentions among the most well-off was also noticed, suggesting that high financial standing may expose people to stressful situations (Hołyst 2002). These studies have also shown that men are more likely to experience suicidal thoughts than women. Men more often than women consider an incurable disease a reason for suicide, and men more often than women consider the death of a loved one a reason justifying a suicide attempt. Men more often than women see the lack of meaning in life as a sufficient reason justifying a suicide attempt. The cit- 
ed studies confirmed that men are more accepting of suicide and more often justify suicide attempts (Hołyst 2002). Perhaps the fact that men are more accepting about the reasons for suicide translates into the fact that, in particularly difficult situations, they themselves decide to attempt and to complete suicide more often than women.

Age: Joe and Niedermeier (2006) reviewed the state of professional knowledge and suicide research in the field of social work. The main conclusion of their work was to notice the increase in the suicide rate in recent years among young men (15-44 years old) and the decrease in the suicide rate for older men, over 45. Studying men's suicidality across the lifespan gives the impression that the average age of men completing suicide has decreased. Suicidal behaviors occur with higher ratios in groups of people with certain characteristics. These groups include adult children of parents who killed themselves, members of families in which somebody completed suicide, and people living with AIDS. A higher rate of suicide was found among survivors of sexual and physical abuse but also among perpetrators of sexual abuse. Well-known risk factors for suicidal behaviors such as mental health problems, including depression and substance abuse (Cavanagh et al., 2003), were also discussed. Joe and Niedermeier (2006) found many differences concerning the incidence of suicide related to gender as well as age. They found differences depending on range of age of the sample population and on the culture and environment where people live.

Hołyst's research shows that suicides are the result of many factors and motivations and that people aged 31-50 are particularly at risk of suicide because they react differently to feelings of alienation than young people. In addition to external factors, frustration resulting from the knowledge of immediate threats and feelings of an individual's powerlessness affect the middle-aged differently than the young (Hołyst 2002). People over 70 are less likely to complete suicide. The motives are different for men and women. Women more often complete suicide due to mental illness and chronic disease, and men more often complete suicide for economic and family reasons (Hołyst 2002). Suicides in people aged around 50 are completed by those who have experienced significant difficulties or injuries that they have not been able to cope with. Such people often have difficulty verbalizing their feelings. The cause of suicide lies more in the development of the personality and life situation than in the acute state immediately preceding suicide (Ringel 1990). However, Conner and coauthors (2012) found that people who abuse alcohol may attempt suicide within a short period after experiencing stressful life events. The focus of the research may lead to a different conclusion that might contradict other findings. For example according to Osgood (1991), the suicide rate among people aged 65 and over is 50\% higher than among people aged 15-24 and increases systematically throughout old age. With age, the number of suicide attempts decreases and the number of completed suicides increases. A special group of those competing suicide are divorced and elderly widowed people (Osgood 1991). For those widowed, the death of a spouse is an acceleration of their own death, and the number of suicides in this group is highest in the period from six to twelve months after the loss of a loved one. The suicide rate is twice as high among men (Baumann 2008), which may lead to the conclusion that men's loneliness after the death of a spouse is harder to bear or that men have fewer, active 
social supports in place after the death of a spouse. There is a well-known "gender paradox" that confuses many researchers who try to understand gender differences in self-destructive behaviors.

Mental Health and Help-Seeking: Women, more often than men, report suicidal ideations and men more often attempt and succeed in completing suicide than women (Freeman et al. 2017; Czabański \& Mariański 2018). Men’s suicidal behaviors may not follow any signaling of distress. The impact of mental health can be different for each gender with greater significance of depression in women's lives and more significant consequences of substance abuse for men. Personal loss, like divorce or the death of a spouse, can be especially detrimental for elderly men and have varied effects for women, depending upon the study.

Depression is a factor that increases the likelihood of suicide among both men and women. However, the number of suicides among men suffering from depression is two to four times higher than among women, and the risk of suicide in men clearly increases after the age of 45-50 (Pużyński 1997). It can also be hypothesized that during a crisis situation, men use psychological help less often than women, which may be a sign of an ideal masculine stereotype. Research has confirmed that men use psychological help less often than women (Kessler, Brown, \& Broman 1981), and they do so only when absolutely necessary. Moreover, many men treat asking for help as a sign of their weakness and helplessness (Möller-Leimkühler 2002). The work of Oliffe and his colleagues (2020) questions such an explanation of men's suicidality. The authors cited studies on men's help-seeking behavior, showing that men often use mental health services before suicide. Unfortunately, not much is known concerning their openness when discussing their conditions with mental health professionals and what kind of help they received (Oliffe et al. 2020). Płaczkiewicz (2019) described individual and social causes of suicidal behavior. She concluded that the main source of men's emotional pain that may lead to suicide is loneliness and a lack of attachment to another human.

According to an interview with Daria Biechowska from the Polish Suicidology Society (Olender 2019), there are few if any suicide prevention programs in Poland. Polish men feel a significant responsibility to be "the breadwinner". They do not have enough support when things are not going well and quickly lose self-esteem when they cannot meet their roles in society. The statistical picture of a Polish man who completes suicide is between $35-60$ years old, unemployed, with a substance abuse problem, and lives in a small city or village. There is an additional problem with the stigmatization of suicidal behavior in small cities, indicating that the stressors must be greater than the perceived stigma.

Different professions, such as social work, sociology, and psychiatry present different pictures of suicide. Research by a team of psychiatrists from Warsaw argues that it is not possible to precisely determine the profile of a suicide. However, based on the analysis of some characteristics of patients who made suicide attempts, these psychiatrists contend that a male who completes suicide has no qualms about applying coercion and manipulation toward someone whose favor he wants. Their characterization continues to describe these men as ambivalent in interpersonal relations, 
quarrelsome, and defensive, and having difficulty adapting to the everyday social expectations. Men completing suicide characterize themselves as "losers" and struggle to formulate and achieve goals. The researchers add that, among the features in this portrait, such a man may seem conservative in contacts and not inclined to act in complex, unclear situations. He has a tendency to change, and at the same time he may not control the limit of his abilities. However, this set of features applies to young men (Koweszko et al. 2018). It is worth noticing that the characteristics of psychiatry patients who made suicide attempts are formulated according to the medical model of mental health. Nursing and social work practitioners use a trauma-informed care approach that avoids stigmatizing language and use a person-in-environment model to capture the dynamic relationships affecting the individual (Kelly et al. 2014).

Suicidal Ideation: In search of an answer to the question why men commit suicide more often, one can refer to the studies by Galasiński and Ziółkowska, who show a relationship between thoughts of suicide and descriptions of suicidal thoughts (based on information collected in the form of recordings of psychiatric interviews in three psychiatric hospitals). These researchers point out that women construct suicide attempts as potentially beyond their control. Men's narratives show that they are in control of a suicide attempt, as if they were choosing an option. Galasiński and Ziółkowska pay attention to patients’ ignoring and simplifying the experience of having suicidal thoughts, which are constructed as homogeneous thoughts about committing and planning suicide. The authors argue that the literature on suicide ignores the experiences of those who think about and try to commit suicide. The authors demonstrate that their initial consideration of the complexity of suicidal thoughts proves that these people are marginalized and treated as irrelevant in accounts of suicide attempts (Galasiński \& Ziółkowska 2013).

The research of Justyna Ziółkowska (2016) is also noteworthy. According to Ziółkowska, doctors focus mainly on confirming the occurrence of suicidal thoughts, but patients in psychiatric hospitals talk about various aspects of their suicidal experiences. Ziółkowska’s research is based on fifty partially structured interviews conducted among people after suicide attempts while hospitalized in psychiatric institutions. Ziółkowska claims that people with an internal locus of control believe that they control their own lives, and people with an external locus of control are convinced that their lives are controlled by factors independent of them. Ziółkowska refers to the well-known concept of Shneidman from 1993 and believes that there are three main dimensions of the suicide model: pain, disorder, and pressure. Ziółkowska proves that men have a greater acceptance and a more lenient attitude towards suicidal behavior than women (2016: 87). Such an attitude may be considered as a factor that facilitates making decisions about the final parting with life. Ziółkowska cites the findings of Shneidman (1996: 59), who assigned a special role to perceptual narrowing. This narrowing boils down to the belief that suicide is the only choice and the only possibility.

Protective Factors and Suicide: To understand gender differences in suicide behaviors some researchers study protective factors that decrease the suicide occurrence for women. They found that populations of women who are religious (VanderWeele 2016) or married or have children have lower rates of suicide (Høyer \& Lund 1993). 
It is interesting that the protective effect of religion is not observed in research concerning men (Stack 1983). The risk factors for suicide for men are unemployment and frustration with underemployment during economic crises (Van Hal 2015). Men's use of alcohol and unhealthy lifestyles also contribute to indirect self-destruction. The results of studies by other researchers confirmed these observations (Jarosz 1997, 2004). The portrait of a suicidal male is a person who is not achieving his goals and is discouraged, feels defeated, and is fearful of the future (Koweszko et al. 2018). In general, depending on the time and place of the research, we can observe that any protective factor may have differential effects on the suicide ratio for both genders. For example, researchers have published data showing that being a father can be either a barrier to suicide (Coleman 2015) or risk factor for men (Pawlak et al. 2018).

Scourfield, in his work on Suicidal Masculinities (2005), discussed the gender difference in RSO, surveying sociological studies. In Table 1 of his work he presented a summary of his research that shows very similar findings as in the social work research of Joe and Niedermeier. He referred to religiosity and social support systems as protective factors against suicide among women. Women may well understand the underlying effect of depression on suicide and be willing to seek and accept help. To explain the different methods of suicide among men and women he concluded that women have negative attitudes toward lethal suicidality, especially with the application of firearms. Concerning men, he specified that more men abuse alcohol than women, which can also lead to differences in RSO. Scourfield's logic focused on the role of a dominant model of hegemonic masculinity as a risk factor for lethal suicidality. Men kill themselves when they cannot achieve the ideal of being a man. He also noted that there is insufficient research concerning the significantly higher prevalence of suicide among men compared to women.

As we mentioned earlier, discussions and explanations of higher RSO for men compared to women usually address differences in suicide protective factors for women and risk factors for men. Though these are important and valid studies, they do not explain the magnitude of the RSO difference between men and women. As Scourfield (2005) observed, many authors compare suicidality among men and women without paying attention to specific gender groups, such as men with a different sexual orientation. He also said that researchers often respond to public discussion on contemporary findings, such as an increase in suicide among young men, and relate their work to the changes in the model of masculinity in mainstream culture. Public discussion about social equality, human rights, and hegemonic masculinity may significantly affect current social research. Recently, more and more authors agree that the masculine ideal oppresses men, and they conclude that different, more inclusive masculinities are better for men's well-being (Nagel \& Mora 2010; Klingemann \& Gomez 2010).

\section{IMPACT OF HEGEMONIC MASCULINITY AND SUICIDALITY}

The concept of hegemonic masculinity can be used to discuss the higher rates of suicide among men in Poland. Those who are part of a minority group will experience additional discrimination as well as lower level of societal supports. In 2017, the Central 
Statistical Office of Poland (GUS) presented data concerning the social perceptions of discrimination in Poland. The least socially desirable group were the homeless; $63 \%$ of respondents cited homeless people as socially undesirable. The second least desirable group were those identified with the LGBT population; $50 \%$ of the respondents said LGBT people were undesirable. The following groups were also discriminated against: poor (41\%); handicapped (40\%); race other than white (34\%); ethnicity other than Polish (25\%); and different religion than Catholic (23\%). In the same data, $7 \%$ of male respondents and $11 \%$ of female respondents said women are discriminated against. Interestingly, women acknowledged that the abovementioned social groups are discriminated against at a rate just slightly higher than that of the responses from men (1-2\%). These numbers increased with the age of the respondents. Another study reported in the same document of GUS (2017) presented people's opinions concerning reasons for social exclusion in Poland. For each group, the percentage of people who agreed the group was socially undesirable is listed in the parenthesis: drug addiction (83.4); mental health problems (81.3); alcoholism (80.5); poverty (75.5); pathological family (74.9); LGBT members (61.1); physical disability (55.7); and old age (43.4). Religion other than Catholic was chosen by 22.5 percent of respondents. Comparisons with the US are difficult, but data from the Pew Research Center indicates that the US reports similar, if not higher, perceptions of discriminated groups. However, statistics concerning the general acceptance of gays and lesbians in the US are improving (McCarthy 2019).

Two areas of difference are that issues of social discrimination in the US are more often publicly discussed than they are in Polish society, and there is a very different historical context for these discussions in Poland and in the US. We can choose one attribute of ideal masculinity at a time and study the impact of this attribute on a man's life. In response to economic recession there are more cases of suicide among men (an $8 \%$ increase compared to $1 \%$ for women) who have problems fulfilling their role as breadwinners. There is also an increase in alcohol abuse related to unemployment and foreclosure. Most affected are men aged 45 to 64 (Kerr et al. 2017). Another attribute of masculinity is bravery. Studies show (Day et al. 2003) that fear is very common among men, but they deny confronting it, which can lead to negative health consequences such as anxiety and depression. According to Galasinski (2008) men feel that depression undermines their masculinity. In general, men avoid looking for help with mental health problems. They very often somaticize their emotional reactions, which affects both their physical and mental health conditions (Frąckowiak-Sochańska 2017).

Each year there is an increase in the rate of suicide among men in the US Army, up to 21.7 per 100,000 in 2009. The authors (Braswell and Kushner 2012) suggest that male soldiers deny any problems related to trauma, PTSD, and other emotional problems due to the ideology of masculinity and that they do not seek help. Polish studies concerning suicide among male soldiers also found that there was an increase in the suicide ratio during the first period of economic transformation (Ilnicki 2018).

A category that arouses interest among suicidologists is the professional police. The research results indicate the significant role of stress, and especially long-term stressful situations, in suicide. Authoritarian relations between superiors and sub- 
ordinates also play an important role (Hołyst 2002). In the case of this professional group, there are several factors that have a significant influence, both resulting from the specificity of the profession and from the specificity of family situations, generated indirectly from the former.

Men's sexuality is clearly affected by attributes of masculinity. The belief that men need to be domineering and unemotional limits their ability to develop intimacy and build healthy partnerships. They may use pornography, created with the vision of men controlling women, as a type of emotionally safe sex (Garlick 2010; Romaniuk 2020). However, when asked about sexual fantasies, men acknowledge that they may have fantasies of being submissive toward women (Hawley \& Hensley IV 2009).

Sexual orientation is an important factor in the etiology of suicides. A study by Danish researchers shows that suicides are significantly more common among gay men than among heterosexual men. According to Malty et al. (2009) suicides are completed eight times more often by gay men than by married heterosexual men. These interesting research findings in Denmark indicate that gay men in relationships are at increased risk of completing suicide. According to Bell and Weinberg, the main cause of suicide attempts among gay men was the breakdown of a relationship (Bell \& Wineberg 1978). A study published in the American Journal of Public Health found gay men completed suicide three times as often as the general American population (21\% created a suicide plan and $12 \%$ attempted suicide, Paul et al. 2002). Both studies in the United States and in some European countries have supported the influence of sexual orientation on the risk of completing suicide, but comparisons are difficult due to methodological differences. However, it can be assumed that the reality of homophobic attitudes in Poland, fueled by the open and official governmental aversion toward those who identify as LGBT (Odrowąż-Coates 2015), create a hidden dynamic that coexists with other factors.

\section{HEGEMONIC MASCULINITY AND MINORITY GROUP STRESS}

Members of minority groups are perceived as "other"; they are often stigmatized and labeled with negative stereotypes (Królikowska 2011; Iniewicz et al. 2012; Dottolo \& Stewart 2008). One of the most stigmatized groups includes those with a different sexual orientation and those who identify as transgender (Paul et al. 2002; Kowalska 2018; Palmer \& Clegg 2020). People of minority groups, besides their specific problems (such as homelessness, disability, or mental health symptoms), deal with minority stress as the result of stigmatization and social exclusion (Nystedt et al. 2019; Królikowska 2011; Iniewicz et al. 2012). The effects of such stress are the same as of any other chronic stressful condition and lead to many physical and mental health problems such as high blood pressure, diabetes, headaches and muscle pain, anxiety, and depression. According to Grabski and his colleagues, bisexual orientation and its dimensions constitute the greatest risk of developing mental disorders (Grabski et. al. 2012). They conclude that living in a hostile environment gives rise to mental health problems and minority group stress.

When men believe that they are insufficiently masculine, they may also experience 
a so-called discrepancy stress in their life (Reidy et al. 2014). It usually starts at a young age and may take the form of bullying (Rosen \& Nofziger 2019); intimate partner violence (Reidy et al. 2014); or sexual abuse toward both women and men (Romaniuk \& Loue 2017). These stresses, with all their effects, can lead to suicide (Chu et al. 2010).

\section{TWO HYPOTHESES}

In both the US and Poland the ideal of hegemonic masculinity is similar, and it is fair to assume that males in the US and in Poland experience the pain of not meeting the perfect model. However, we still need to consider why the ratio of men's suicide over women's is twice as high in Poland as in the US. It is a significant difference, especially since the ratio in Poland is one of the highest worldwide. There are two hypotheses: 1 ) The hegemonic ideal of a man creates more significant social pressure in Poland, and 2) The pattern of alcohol consumption in eastern Europe is more detrimental to the well-being of men.

Alcohol consumption and suicidality: According to Landberg (2008), men in Eastern Europe drink alcohol such as vodka, which may more quickly lead to addiction with comorbid physical and mental illnesses. Problems with health and behavior among men affected by alcoholism lead to unemployment and poverty. The consequences of drinking are risk factors for suicide among men and would explain the higher RSO when compared with countries in which less destructive drinking patterns are present (Landberg 2008). We suggest that men in Poland practice heavy drinking as an attribute of "being a man" (Lemle \& Mishkind 1989). If we assume that heavy drinking is a demonstration of the expression of masculinity, then we have only one hypothesis explaining higher RSO for men: the hegemonic ideal of masculinity results in self-destructive behaviors.

Hegemonic masculine ideal and suicidality: What is the difference between the US and Poland in the social pressure on men to achieve the masculine ideal? First, it is the traditional role of marriage and the positions of a man and a woman in the family. The conservative outlook on family in Poland is reinforced by messages that people receive from the Catholic Church. Even the Communist Party, before 1989, supported the conservative attitude concerning the role of family in the society; it was easier to control people who had to provide for their families. After the economic transformation of 1989 and the confusing policies concerning the place of women in the job market (Saxonberg \& Szelewa 2007; Ramet 2017), the public discussion concerning the right to an abortion revived the efforts of Church and government officials to establish men's political control over women rights (Szwed 2019; Calkin \& Kamińska 2020).

Although the influence of the Catholic Church in Poland increased significantly after 1989, the public support of the Church and its role in family life started to decline (Kissling 1991). From 2003 to 2013 the number of divorces increased 35\% and a majority of Poles were in favor of same-sex civil partnerships. In recent years, the increase in collaboration between government and Catholic authorities is associated with the decrease in public trust toward Catholic teachings (Ramet 2017).

Systematic racism and homophobia are still present in American society. While 
there is still much work ahead to confront the culture of discrimination and social exclusion, there has also been some significant progress. Gays and lesbians can marry and serve in the military, unthinkable just decades ago. Being gay is more acceptable in today's America and gay men can benefit from more legal protections than ever before (McCarthy 2019). In contrast, gays in Poland were never accepted socially, they have no rights to marry, they cannot serve in the military, and they are not legally protected. Tension that is created by religious leaders produces anxiety and chronic stress in the lives of gay men in Poland (Zarzycka, Rybarski, \& Sliwak 2017). Governing party officials and bishops of the Catholic Church have identified what they call "gender ideology" (Szwed 2019), which recently they replaced with "LGBT ideology” while literally dismissing the humanity of those who identify as LGBT. These political and religious leaders regularly demonize the so-called "LGBT ideology", and many cities in Poland have designated themselves as "LGBT free zones" (Crowley 2020). When homophobia in Poland is used in politics together with other tropes of the conservative right, such as patriotism and Polish traditions, then advocating for gay equity becomes very difficult (Graff 2010). Similarly, Golebiowska (2017) asserts that LGBT activism for equality in Poland meets with political barriers when arguments of patriotism and nationalism are put in opposition to cultural compatibility with the European Union.

For men in a society that affirms hegemonic masculinity, any sign of femininity is interpreted as being weak and not being able to stand up for himself. He may well be afraid of being called a "sissy" (gay). This fear, which is simply called homophobia, affects both straight men and gays. Young boys in Poland who discover an interest in the same sex have no information and no successful role models for being gay. However, they have plenty of negative descriptions of who is gay available in their environment. When they hear that being gay is equivalent to being a pervert or when they hear homophobic remarks from parents and friends, then they become unwilling to face their sexual orientation. They may try to build an identity of a straight man, using the role models available around them. The same is applied to a straight man whose traits or personality might include characteristics some identify as more feminine or gay (Sánchez et al. 2009; Fasoli, Hegarty, \& Frost 2021). They can be called "sissy" by colleagues or be mocked. To avoid such situations, they internalize homophobic messages to conform with the ideal of a hegemonic man, in the process denying their real personality. As a consequence, both gays and straights may experience a lack of self-esteem and self-confidence; they may even develop self-hate because of their apparent "perversion". In both these cases, men may look to self-destructive behaviors to relieve their stressful situations, often leading to the development of chemical and behavioral addictions (Tsirigotis et al. 2015; Landberg 2008). Research has shown that LGB youth are at greater risk for depression and substance abuse. Nearly one third (29\%) of LGB youth had attempted suicide at least once in the prior year compared to $6 \%$ of heterosexual youth (Lyons et al. 2019).

Much higher numbers for suicide ideation (46.55\%) and suicide attempts (27.19\%) are reported among the population of transgender men (Adams \& Vincent 2019). This is the most vulnerable group of men, a group exposed to considerable discrimination 
and violence. Men whose sex assigned at birth was female and who were socialized in childhood to some expected role of a woman in society struggle with integrating masculinity into their identities. Understanding their own femaleness and seeing being a man as their goal, they hardly acknowledge their masculinity. They instead identify themselves as "trans men" in the midst of going through the process of becoming a man (Seamont 2018). From the perspective of the individual, they might achieve the most inclusive form of masculinity but they are met with distrust, a lack of understanding, and transphobia by the rest of society, leading to drastic forms of social exclusion (Konopka et al. 2020; Palmer \& Clegg 2020) and higher rates of suicide (Adams \& Vincent 2019).

Research conducted among people with a non-heteronormative orientation in Poland from 2015 to 2016 shows that this group struggles with many problems in their lives (Świder \& Winiewski 2017). Those with a non-heteronormative orientation experience a sense of loneliness, a lack of acceptance from family, discrimination by health care staff, and manifestations of inferior treatment in the living environment and at work. They also experience violence and hate speech and struggle with depression. It should be added that negative attitudes towards the non-heteronormative Poland are currently fueled by the Church and the ruling political party. The list of hidden problems experienced by people of different sexual orientations is quite long, but most of all they experience minority stress. Research has confirmed that the number and scope of problems experienced by this social category are mainly influenced by the environment, education, and gender (Kotlarska-Michalska 2019b). The families of the LGBT population are often hidden, because they threaten the official moral standards dictated by religious and political doctrine in three ways: 1) they are an expression of informal relationships; 2) they include children who are raised by "evil" role models; 3) and they bring out moral panic in the community (Kotlarska-Michalska 2019b).

It is documented that having a family is a protective factor against suicide. That means that losing a family or having family problems can be a risk factor for suicide. It is possible, that in Poland, where family is such a center of social life, family problems would have more meaning as a risk factor for suicide than in the US. Research has shown (Olesiński 2012) that marriage comes in second, just after good health, as most important in people's lives in Poland. It is worth mentioning that the divorce rate in Poland is about 1.8 per 1000 whereas in the US it is 3.2 , evidence of a relatively more relaxed approach to institution of marriage in America. For gay people in Poland, who cannot get married, the protective role of marriage does not exist at all (Olesiński 2012; Iniewicz et al. 2012).

The issue of paternity among gays is addressed by researchers in Poland (Mizielińska, Struzik, \& Król 2017) who believe that there is a relationship between the degree of social homophobia and the model of non-heterosexual fatherhood. Reducing the level of homophobia influences the change of expectations towards men, who may fulfill themselves in patterns of being a man other than hypermasculinity. A significant obstacle in Poland is the fact that the parentage of two men is not legally or institutionally or culturally legitimized. These researchers argue that the socialization of men is limited to an ethics of care and housework, contradicting the male model 
of fatherhood and masculinity. Gay fatherhood is a hidden problem and completely invisible, resulting from the fact that homosexuality is hidden in family and social relationships.

On the basis of the literature cited in this paper, we suggest that the main reason for the higher RSO for men compared to women is the ideal of hegemonic masculinity that all men are supposed to strive for. The two times higher RSO rate in Poland compared to the US may be the result of the stronger effect of hegemonic masculinity in a conservative society with significantly more homophobia and discrimination against sexual minorities, negatively affecting all men (Crowley 2020).

\section{CONCLUSIONS AND IMPLICATIONS FOR SUICIDE PREVENTION}

Jacek Kochanowski, the author of a book on the sociology of sexuality, writes that the modern world is no longer a homogeneously male world and there is a possibility to question all hegemony. Such questioning opens up the social space to politics, difference, otherness, and antagonistic procedures enabling the consideration of various desires and interests. This means a gradual dismantling of the system of compulsory heterosexuality (Kochanowski 2013). Kochanowski analyzes various strategies that can help men overcome their paranoid fear of what is feminine, the fear that results in aggression towards women. The strategy of consciously overcoming the boundary between masculine and feminine is very difficult.

There are many studies concerning how to help men when they experience suicidal ideations or have attempted suicide (Joe \& Niedermeier 2006; Sobkowiak 2011). Usually this help involves specific substance abuse and/or mental health treatment interventions (Seaton et al. 2017; Frąckowiak-Sochańska 2017) or a more systemic family approach (Kołodziej 2016; Hunt et al. 2017). However, since we believe that the main reason for the disproportionate suicide rate is the ideal of the hegemonic man, we address this concept as a core issue in designing prevention efforts.

We believe that the ideal of hegemonic masculinity is a central source of stress and the mental health problems of men who deal with social pressure to adjust to this ideal. The final stage of such conformity would be escape from a stressful life through suicide (Braswell \& Kushner 2012). There has also been a call to reject the ideal of masculinity; this is the opinion of Stoltenberg (p. 365), as described by Berggren (2015).

Another way of dealing with the effects of hegemonic masculinity is to reframe the concept of access to resources. In this case the issue of social control is not inherently tied with the male gender but with those who own wealth. In today's world it is not difficult to imagine a woman having better access to resources and the ability to foresee how society needs to change to make conditions easier for her. With this simple reframing of power tied to one gender, we can open our thinking to all genders (Russell 2019; Hawley \& Hensley IV 2009).

Most of the research cited here points out the role of hegemonic masculinity in creating the hierarchy of power, with the strong, married, heterosexual white man on top. Each time he demonstrates a behavior not in accordance with an attribute of that ideal, his standing in society and his individual perception lowers his position of priv- 
ilege. However, it has also been shown that there is not one model of masculinity but many concepts of masculinities. In the study of men who were infected with HIV, it was found that although illness as a weakness affected their privileged position, a man can present himself favorably by redefining his status as a responsible person who takes care of his health (Russell 2019). Eric Anderson (Nagel \& Mora 2010) in his work on inclusive masculinity suggests that masculinity may not be defined in opposition to either femininity or homosexuality.

The ideal of hegemonic masculinity is built on the preference of one gender and discrimination of the other. Such a global concept affecting the lives of all people has profound consequences. It is not surprising that a culture such as Poland's, built on this concept, avoids questioning it. In general, sexual education (or lack of it), sex relations, sexual behaviors, and sexual orientations are all topics that are to a great extent controlled by a unitary expression of Polish culture creating a hegemonic view of masculinity with pressures to conform resulting in suicidal behaviors among men. In everyday life authorities such as politicians, lawmakers, and religious teachers tell people what is appropriate concerning human sexuality and masculinity. Since this state of affairs creates problems for society, such as those described in this paper, society should, at the very least, question the ideal of hegemonic masculinity as part of society changes to decrease suicidal behaviors.

While the literature concerning the LGBT population is rich in examples of how social stigma and stereotypes affect the life and health of this population, it also presents many examples of how the LGBT community helps and supports its members. In recent decades, the positive description of LGBT people has become more common in mainstream culture (Wacławik 2011). Although statistics show that about half of the population in Poland and the US still believe that LGBT people are discriminated against, these results are lower than in previous decades. Presenting positive role models and creating positive literature concerning the LGBT community is a step forward in diminishing stigma and the negative perception of sexual minorities and as a first step in the prevention of mental health issues, alcohol use, and suicidal behaviors. Although researchers found that there is not enough educational material for schools on how to educate about sexual minorities (Kołodziej 2016), there is more and more quality research available concerning sexual minorities in the Polish language (Olesiński 2012; Iniewicz et al. 2012) especially concerning parenting (Kołodziej 2016; Kowalska 2018).

One of the problems of same-sex couples is relatively little knowledge about malemale relationships, making it impossible to build a positive image of a gay couple. Discrimination and a lack of acceptance often lead gay men to develop their own specific coping strategies based on getting support from their own communities. These strategies may have a positive effect on relationship building (Olesiński 2012). It is interesting that the suicide prevention strategies for men described by Oliffe and coworkers (2020) are the de-stigmatization of mental health, peer and community support, and the promotion of health care seeking behavior as an act of self-reliance and independence.

The research concerning men in substance abuse treatment programs offers an- 
other avenue for change. Clients of the treatment program were asked about topics that they felt were not addressed by therapy. They said that all issues related to sex and family problems were avoided by therapists and were exactly the topics that they struggle with and that they need to deal with for the sake of long term sobriety. More research is called for to meet the needs of men in therapy (Klingemann \& Gomez 2010).

It is also suggested that some of the attributes of masculinity, such as bravery and responsibility, can be used as clients' strengths to build motivation for change (Frąckowiak-Sochańska 2017). Kuehn (2009) described suicide prevention methods for the US military consisting in the de-stigmatization of mental health, improving access to health care, and the development of a so-called "battlemind", which is the application of a soldier's skills developed in military training to everyday life. Others have suggested that military training for both men and women can be re-framed from the perspective of performance rather than from the perspective of the masculine ideal (Boldry, Wood, \& Kashy 2001). In addition, the theory of patriarchy, as well, expands the framework beyond the masculine ideal to discuss gender hierarchy in today's society (Soman 2009).

Bałandynowicz points to the need to target presuicidal prophylaxis at two types of recipients: 1 ) the family (here the activities should consist of preparing individuals for the proper performance of roles in the family, that is, motherhood and fatherhood); 2) the general public, in order to debunk the myths and stereotypes about suicide and to encourage the public to adopt attitudes of understanding, acceptance, and kindness (Bałandynowicz 2014). The current state of knowledge about the causes of suicide among men should be used to build special programs for those most vulnerable to completing suicide and to encourage men to seek psychological help and to discuss their struggles openly. These smaller programmatic changes must take place within broader societal efforts to reduce hegemonic masculine ideas and provide more inclusive elements into society in the hopes of reducing suicide rates among Polish men.

Funding: This research received no external funding.

Conflicts of Interest: The authors declare no conflict of interest.

\section{REFERENCES}

Adams, Noah \& Ben Vincent. 2019. "Suicidal thoughts and behaviors among transgender adults in relation to education, ethnicity, and income: A systematic review." Transgender health 4(1): 226-246 DOI:10.1089/trgh.2019.0009

Bałandynowicz, Andrzej. 2014. „Profilaktyka i prewencja zachowań suicydalnych w okresie adolescencji u dzieci i młodzieży.” Resocjalizacja Polska 6: 17-40.

Baumann, Katarzyna. 2008. „Problem aktów samobójczych wśród osób w starszym 
wieku." Gerontologia polska 16(2): 80-88.

Barłowski,Dezydery.2018.„Homoseksualność-homofobia-nacjonalizm-męskość. Teoretyczne relokacje.” Wielogłos, UJ3(37):21-35DOI:10.4467/2084395XWI.18.027.10191

Bell, Alan P. \& Martin S. Weinberg. 1978. Homosexualities. A Study of Diversity among Men and Women. New York: Simon and Schuster.

Berggren, Kalle. 2015. „Lepka męskość: Poststrukturalizm, fenomenologia i podmiotowość w krytycznych studiach nad męskością." Uppsala University, Disciplinary Domain of Humanities and Social Sciences, Faculty of Social Sciences, Department of Sociology. Retrieved July 5, 2020 (http://uu.diva-portal.org/smash/record. jsf?pid=diva2\%3A840059\&dswid=-8350).

Bieńkowska, Małgorzata. 2011 „Gender i wielokulturowość.” Pogranicze. Studia Społeczne 43: 26-44.

Binczycka-Anholcer, Marzena. 2005. „Zachowania suicydalne osób w starszym wieku.” Suicydologia 1: 77-87.

Boldry, Jennifer, Wendy Wood, \& Deborah A. Kashy. 2001. "Gender stereotypes and the evaluation of men and women in military training." Social Issues 57(4): 689-705. https://doi.org/10.1111/0022-4537.00236

Braswell, Harold \& Howard I. Kushner. 2012. "Suicide, social integration, and masculinity in the U.S. military.” Social Science and Medicine 74(4): 530-536. DOI: 10.1016/j.socscimed.2010.07.031

Calkin, Sydney \& Monika E. Kaminska. 2020. "Persistence and change in morality policy: The role of the Catholic Church in the politics of abortion in Ireland and Poland." Feminist Review 124: 86-102.

Cavanagh, Jonathan T. O., Alan J. Carson, Michael Sharpel, \& Steven M. Lawrie. 2003. "Psychological autopsy studies of suicide: A systematic review." Psychological Medicine 33: 395-405.

Chu, Joyce P., Peter Goldblum, Rebecca (Becca) Floyd, \& Bruce Bongar. 2010. “The cultural theory and model of suicide.” Applied and Preventive Psychology 14(1-4): 25-40.

Coleman, Daniel. 2015. "Traditional masculinity as a risk factor for suicidal ideation: Cross-sectional and prospective evidence from a study of young adults.” Archives of Suicide Research 19(3): 366-384. DOI: 10.1080/13811118.2014.957453

Coleman, Daniel, William Feigelman, \& Zohn Rosen. 2020. “Association of high traditional masculinity and risk of suicide death: Secondary analysis of the Add Health study (Letters).” JAMA Psychiatry 77(4): 435-437.

Connell, Raewyn W. 2002. "On hegemonic masculinity and violence: A response to Jefferson and Hall." Theoretical Criminology 6(1): 89-99.

Conner, Kenneth R., Rebecca J. Houston, Marc T. Swogger, et al. 2012. "Stressful life events and suicidal behavior in adults with alcohol use disorders: Role of event severity, timing, and type." Drug and alcohol dependence, 120(1-3): 155-161. doi. org/10.1016/j.drugalcdep.2011.07.013

Cortes, Laura R., Carla D. Cisternas, \& Nancy G. Forger. 2019. “Does gender leave an epigenetic imprint on the brain?” Frontiers in Neuroscience. February 27 DOI: 10.3389/fnins.2019.00173 
Crowley, Michael. 2020. "Poland's right-wing president meets with Trump and gets a pre-election boost.” The New York Times. June 24. Retrieved July 5, 2020 (https:// www.nytimes.com/2020/06/24/us/politics/trump-andrzej-duda-poland.html).

Czabański, Adam \& Janusz Mariański. 2018. „Problematyka samobójstw w ujęciu Marii Jarosz.” Teologia i Moralność 13(2): 225-241.

Day, Kristen, Cheryl Stump, \& Daisy Carreon. 2003. "Confrontation and loss of control: Masculinity and men's fear in public space.” Journal of Environmental Psychology 23(3): 311-322. DOI: 10.1016/S0272-4944(03)00024-0

de Boise, Sam. 2019 “Editorial: Is masculinity toxic?” NORMA 14(3): 147-151. DOI: 10.1080/18902138.2019.1654742

Dottolo, Andrea L. \& Abigail J. Stewart. 2008. “Don’t ever forget now, you're a Black Man in America: Intersections of race, class and gender in encounters with the police." Sex Roles 59: 350-364. DOI: 10.1007/s11199-007-9387-x

Dublin, Louis, I., \& Bessie Bunzel. 1933. To Be or Not To Be; A Study of Suicide. New York: Random House.

Durkheim, Emil. 1897/1951. Suicide: A Study in Sociology. New York: Free Press.

Fasoli, Fabio, Peter Hegarty, \& David M. Frost. 2021. "Stigmatization of 'gay-sounding' voices: The role of heterosexual, lesbian, and gay individuals' essentialist beliefs.” British Journal of Social Psychology Open Access. DOI:10.1111/bjso.12442

Fine, Cordelia, John Dupré, \& Daphna Joel. 2017. "Sex-linked behavior: Evolution, stability, and variability." Trends in Cognitive Sciences 21(9): 666-673. DOI: 10.1016/j.tics.2017.06.012

Frąckowiak-Sochańska, Monika. 2017. “Mężczyźni w procesie psychoterapii a normatywne schematy męskości - ciągłość i zmiana.” Miscellanea et Sociologica 18(2): 91-114.

Freeman, Aislinné, Roland Mergl, Elisabeth Kohls, et al. 2017. “A cross-national study on gender differences in suicide intent.” BMC Psychiatry 17: 234. DOI: 10.1186/ s12888-017-1398-8

Galasiński Dariusz \& Justyna Ziółkowska. 2013. “Experience of suicidal thought: A discourse analytic study”. Communication \& Medicine 10(2): 117-127.

Galasiński, Dariusz. 2008. “Lesser Men. Depression and the model of masculinity.” Pp. 121-135 in Men's Discourses of Depression. London: Palgrave Macmillan. https:// doi.org/10.1057/9780230227620_8

Garlick, Steve. 2010. “Taking control of sex?: hegemonic masculinity, technology, and internet pornography." Men and Masculinities 12(5): 597-614. DOI: $\underline{10.1177 / 1097184 X 09341360}$

Gibson, Alastair. 2007. “Erikson's life cycle approach to development.” Pp. 74-85 in Handbook for Practice Learning in Social Work and Social Care. $2^{\text {nd }}$, edited by J. Lishman. London \& Philadelphia: Jessica Kingsley Publishers.

Golebiowska, Ewa. 2017 “The links between gender role beliefs, conceptions of the family, attitudes toward Poland's membership in the European Union, religiosity, and Polish support for gay and lesbian rights." Politics, Groups, and Identities 5(4): 599-617. DOI: 10.1080/21565503.2016.1146151

GUS (Główny Urząd Statystyczny). 2017. Jakość życia w Polsce w 2015 r. Wyniki badania 
spójności społecznej. Warszawa: Studia i Analizy Statystyczne.

Grabski Bartosz, Grzegorz Iniewicz, \& Magdalena Mijas. 2012. „Zdrowie psychiczne osób homoseksualnych i biseksualnych - przegląd badań i prezentacja zjawiska.” Psychiatria Polska 46(4): 637-647

Graff, Agnieszka. 2010. "Looking at pictures of gay men: Political uses of homophobia in contemporary Poland.” Public Culture 22(3): 583-603. DOI 10.1215/089923632010-010

Hamidi, Oksana \& Todd B. Nippoldt. 2019. “Biology of gender identity and gender incongruence.” Pp. 39-50 in Transgender Medicine. Contemporary Endocrinology, edited by L. Poretsky \& W. Hembree. Cham: Humana Press. DOI:10.1007/978-3-030-056834 _3

Hawley, Patricia H. \& William A. Hensley IV. 2009. "Social dominance and forceful submission fantasies: Feminine pathology or power?” The Journal of Sex Research 46(6): 568-585. DOI: $10.1080 / 00224490902878985$

Höfer, Peter, Ian R. Rockett, Peeter Värnik, Elmar Etzersdorfer, \& Nestor D. Kapusta. 2012. "Forty years of increasing suicide mortality in Poland: Undercounting amidst a hanging epidemic?” BMC Public Health 12: 644. https://doi.org/10.1186/1471-245812-644

Høyer, Georg \& Lund Eiliv. 1993. "Suicide among women related to number of children in marriage.” Archives Of General Psychiatry 50(2): 134-137. DOI:10.1001/ archpsyc.1993.01820140060006

Hołyst, Brunon. 2002. Suicydologia. Warszawa: Wyd. LexisNexis.

Hunt, Tara, Coralie J. Wilson, Peter Caputi, Alan Woodward, \& Ian Wilson. 2017. "Signs of current suicidality in men: A systematic review.” PLoS ONE 12(3): e0174675. DOI: 10.1371/journal.pone.0174675

Ilnicki, Piotr. 2018. „Analiza samobójstw żołnierzy w okresie transformacji Sił Zbrojnych RP w latach 2000-2012.” Repozytorium WIM. Retrieved July 5, 2020 (http:// hdl.handle.net/20.500.12564/123).

Iniewicz, Grzegorz, Bartosz Grabski, \& Magdalena Mijas. 2012. „Zdrowie psychiczne osób homoseksualnych i biseksualnych - rola stresu mniejszościowego.” Psychiatria Polska 46(4): 649-663.

Joe, Sean \& Danielle Niedermeier. 2006. "Preventing suicide: A neglected social work research agenda.” British journal of social work 38(3): 507-530. doi:10.1093/bjsw/ bcl353

Jarosz, Maria. 1997. Samobójstwa. Warszawa: Wydawnictwo Naukowe PWN.

Jarosz, Maria. 2004. Samobójstwa. Ucieczka przegranych. Warszawa: Wydawnictwo PWN.

Kelly, Ursula, Mary Ann Boyd, Sharon M. Valente, \& Elizabeth Czekanski. 2014. “Trauma-informed care: Keeping mental health settings safe for veterans.” [published correction appears in Issues Ment Health Nurs. 2015 Jun; 36(6):482]. Issues Ment Health Nurs 35(6): 413-419. DOI:10.3109/01612840.2014.881941

Kerr, William C., Mark S. Kaplan, Nathalie Huguet, Raul Caetano, Norman Giesbrecht, \& Bentson H McFarland. 2017. "Economic recession, alcohol, and suicide rates: Comparative effects of poverty, foreclosure, and job loss.” American journal of 
preventive medicine 52(4): 469-475. DOI: 10.1016/j.amepre.2016.09.021

Kessler, Ronald C., Roger L. Brown, \& Clifford L. Broman. 1981. "Sex differences in psychiatric help-seeking: Evidence from four large-scale surveys.” Journal of Health and Social Behavior 22(1): 49-64.

Kissling, Frances. 1991. “The Church's heavy hand in Poland.” Conscience 12(5): 20-1. Klingemann, Harald \& Veronica Gomez. 2010. "Masculinity issues in addiction treatment in Swiss inpatient alcohol programs: Bringing men's treatment needs back to the research agenda." Journal of Men's Health 7(3): 211-220. DOI: 10.1016/j. jomh.2010.04.003

Kluczyńska, Urszula. 2018. “Socjologiczne studia nad mężczyznami i męskościami w Polsce. Obszary, perspektywy, teorie.” Wielogłos, UJ. 3(37): 1-20. DOI: 10.4467/2 084395XWI.18.026.10190

Kochanowski, Jacek. 2013. Socjologia seksualności. Marginesy. Warszawa: Wydawnictwo Naukowe PWN.

Kołodziej, Kosma. 2016. „Dziecko homoseksualne w rodzinie.” Czasopismo Pedagogiczne 2(3): 53-61.

Konopka, Karolina, Monika Prusik, \& Michał Szulawski. 2020. “Two sexes, two genders only: Measuring attitudes toward transgender individuals in Poland.” Sex Role 82: 600-621. DOI:10.1007/s11199-019-01071-7

Korolczuk, Elżbieta. 2020. “Feminism as left-wing populism.” Baltic Worlds 13(1): 92. Kotlarska-Michalska, Anna. 2019a. "Introduction.” Pp. 7-18 in The Invisible Groups in Poland, edited by A. Kotlarska-Michalska, K. J. Farkas, \& R. Romaniuk. Poznań: Wydawnictwo Nauk Społecznych i Humanistycznych, Uniwersytet im. Adama Mickiewicza w Poznaniu. Retrieved July 5, 2020 (http://funhum.home.amu.edu. $\mathrm{pl} /$ sites/default/files/dysponenda/invisible_groups_wstep.pdf).

Kotlarska-Michalska, Anna. 2019b. „Ukryte problemy społeczne - ich przyczyny i specyfika w Polsce.” Human Studies. Series of Pedagogy 9/41: 100-119.

Kowalska, Małgorzata. 2018. „Kulturowe i społeczne konteksty wychowania.” Psychologia Wychowawcza 13: 149-160.

Koweszko, Tytus, Jacek Gierus, Anna Mosiołek, \& Agata Szulc. 2018. “Considerations of suicidal behaviour in psychiatrically hospitalized patients. A psychological portrait of a suicidal female and male." Psychiatria 15(1): 7-12.

Królikowska, Sabina. 2011. „Rola stereotypów płci w kształtowaniu postaw kobiet i mężczyzn wobec zdrowia.” Nowiny Lekarskie 80(5): 387-393.

Kuehn, Bridget M. 2009. “Soldier suicide rates continue to rise.” JAMA 301(11): 11111113. DOI:10.1001/jama.2009.342

Landberg, Jonas. 2008. "Alcohol and suicide in eastern Europe.” Drug and Alcohol Review 27(4): 361-373.

Lemle, Russell \& Marc E. Mishkind. 1989. “Alcohol and masculinity.” Journal of Substance Abuse Treatment 6: 213-222.

Lyons Bridget H., Mikel L. Walters, Shane P. D. Jack, Emiko Petrosky, Janet M. Blair, \& Asha Z. Ivey-Stephenson. 2019. "Suicides among lesbian and gay male individuals: Findings from the National Violent Death Reporting system.” American Journal of Preventive Medicine 56(4): 512-521. DOI:10.1016/j.amepre.2018.11.012 
Malty, Robin M., Susan D. Cochran, Jorn Olsen, \& Vickie M. Mays. 2009. "The association between relationship markers of sexual orientation and suicide.” Denmark, Social Psychiatric Epidemiology 46(2): 1990-2001.

McCarthy, Justin. 2019. "Gallup first polled on gay issues in "77. What has changed?" Gallup, Politics. June 6. Retrieved July 5, 2020 (https://news.gallup.com/poll/258065/ gallup-first-polled-gay-issues-changed.aspx).

Mizielińska, Joanna, Justyna Struzik, \& Agnieszka Król. 2017. „Różnym głosem. Rodziny z wyboru w Polsce.” Warszawa: Wydawnictwo PWN.

Möller-Leimkühler, Anne Maria. 2002. "Barriers to help-seeking by men: A review of sociocultural and clinical literature with particular reference to depression." Journal of Affective Disorders 71: 1-9.

Möller-Leimkühler, Anne Maria. 2003. "The gender gap in suicide and premature death or: why are men so vulnerable?” European Archives of Psychiatry and Clinical Neurosciences 253: 1-8. DOI:10.1007/s00406-003-0397-6

Nagel, Elizabeth G. \& Richard Mora. 2010. “[Book Reviews: Inclusive Masculinity: The Changing Nature of Masculinities, Erotic Journeys: Mexican Immigrants and Their Sex Lives.]" The Journal of Men's Studies 18(1): 109112. DOI:10.1177/106082651001800101

Norko, Michael A., David Freeman, James Phillips, William Hunter, Richard Lewis, \& Ramaswamy Viswanathan. 2017. "Can religion protect against suicide?” The Journal of Nervous and Mental Disease 205(1): 9-14. DOI: 10.1097/ NMD.0000000000000615

Nystedt, Tanya, Maria Rosvall, \& Martin Lindström. 2019. "Sexual orientation, suicide ideation and suicide attempt: A population-based study.” Psychiatry Research 275: 59-365. DOI:10.1016/j.psychres.2019.04.007

Odrowąż-Coates, Anna. 2015. "Gender crisis in Poland, Catholic ideology and the media.” Sociology Mind 5: 27-34. DOI:10.4236/sm.2015.51004

Olender, Aneta. 2019. „Cierpią w samotności. Codziennie dwunastu polskich mężczyzn popełnia samobójstwo.” Na:Temat. October 19. Retrieved July 5, 2020 (https:// natemat.pl/287017,polscy-mezczyzni-w-czolowce-samobojcow-w-europie-nieszukaja-pomocy\#).

Olesiński, Piotr. 2012. „Relacja intymna osób homoseksualnych oraz trudności w jej nawiązywaniu i utrzymaniu." Studia Psychologiczne 50(1): 15-26.

Oliffe, John L., Alex Broom, Emma Rossnagel, Mary T. Kelly, William Affleck, \& Simon M. Rice. 2020. "Help-seeking prior to male suicide: Bereaved men perspectives." Social Science \& Medicine 261: 113-173.

Osgood, Nancy J. 1991. "Prevention of suicide in the elderly." Journal Gerontology Psychology 24: 293-306.

Palmer, Biff F. \& Deborah J. Clegg. 2020. "A universally accepted definition of gender will positively impact societal understanding, acceptance, and appropriateness of health care.” Mayo Clinic Proceedings DOI:10.1016/j.mayocp.2020.01.031

Paul, Jay P., Joseph Catania, Lance Pollack, Judith Moskowitz, Jesse Canchola, Thomas Mills, Diane Binson, \& Ron Stall. 2002. "Suicide attempts among gay and bisexual men: Lifetime prevalence and antecedents.” American Journal of Public 
Health 92(8): 1338-1345. DOI:10.2105/ajph.92.8.1338

Pawlak, Joanna, Izabela Miechowicz, Monika Dmitrzak-Węglarz, Aleksandra Szczepankiewicz, Dorota Zaremba, Paweł Kapelski, Aleksandra Rajewska-Rager, Piotr Czerski, Maria Skibińska, \& Joanna Hauser. 2018. „Czy czynniki związane z ryzykiem samobójstwa są specyficzne dla płci?” Psychiatria Polska 52(1): 21-32. DOI:10.12740/PP/78974

Payne, Sarah, Viren Swami, \& Debbi L. Stanistreet. 2008. "The social construction of gender and its influence on suicide: A review of the literature.” Journal of Men's Health 5(1): 23-35.DOI.org/10.1016/j.jomh.2007.11.002

Pirkis, Jane, Matthew J. Spittal, Louise Keogh, Tass Mousaferiadis, \& Dianne Currier. 2017. "Masculinity and suicidal thinking." Soc Psychiatry Psychiatr Epidemiol 52: 319-327. DOI:10.1007/s00127-016-1324-2

Płaczkiewicz, Beata. 2019. „Analiza wybranych przyczyn zachowań samobójczych wśród osób dorosłych." Rocznik Towarzystwa Naukowego Płockiego 10: 317-329. DOI:10.19251/rtnp/2018.10(12)

Pużyński, Stanisław. 1997. „Samobójstwa i depresje.” Lęk i depresja 2: 139-156.

Razvodovsky, Yury E. 2015. "Alcohol and suicide in Eastern Europe." Journal of Addiction Medicine and Therapeutic Science 1(1): 001-003. DOI: 10.17352/24553484.000001

Ramet, Sabrina P. 2017. "Controversies in the social and political engagement of the Catholic Church in Poland since 1988." Pp. 19-40 in Religion, Politics, and Values in Poland, edited by S. Ramet \& I. Borowik. Palgrave Studies in Religion, Politics, and Policy. New York: Palgrave Macmillan. https://doi.org/10.1057/978-1-13743751-8_2

Reddy, Raghunandan, Arun Kumar Sharma, \& Munmun Jha. 2019. “Hegemonic masculinity or masculine domination: Toward a comprehensive social theory of gender." International Journal of Sociology and Social Policy 39(3/4): 296310. DOI:10.1108/IJSSP-08-2018-0133

Reidy, Dennis E., Danielle S. Berke, Brittany Gentile, \& Amos Zeichner. 2014. “Man enough? Masculine discrepancy stress and intimate partner violence.” Personality and individual differences 68: 160-164. DOI.org/10.1016/j.paid.2014.04.021

Ringel, Erwin. 1987. Gdy życie traci sens. Rozważania o samobójstwie. Szczecin: Wydawnictwo Glob.

Ritchie, Hannah, Max Roser, \& Esteban Ortiz-Ospina. 2020. "Suicide”. Published online at OurWorldInData.org. Retrieved July 5, 2020 (https://ourworldindata.org/ suicide).

Rodziński, Paweł, Krzysztof Rutkowski, \& Anna Ostachowska. 2017. „Progresja myśli samobójczych do zachowań samobójczych w świetle wybranych modeli suicydologicznych.” Psychiatria Polska 51(3): 515-530. DOI:10.12740/PP/63984

Romaniuk, Jarosław R. \& Sana Loue. 2017. "Military sexual trauma among men: A review of the literature and a call for research.” Best Practices in Mental Health 13(1): 81-105.

Romaniuk, Ryszard. 2020. “Kobiety i pornografia.” Terapia Uzależnieńi Wspótuzależnień 2: $26-30$. 
Rosa, Krzysztof. 2012. „(Nie)wiarygodność danych statystycznych dotyczących zachowań samobójczych. Perspektywa teoretyczna i praktyka społeczna." Przegląd Socjologiczny 61(2): 265-263.

Rosen, Nicole L. \& Stacey Nofziger. 2019. "Boys, bullying, and gender roles: How hegemonic masculinity shapes bullying behavior.” Gender Issues 36: 295-318. DOI:10.1007/s12147-018-9226-0

Russell, Steve. 2019. "Men's refashioning of masculine identities in Uganda and their self-management of HIV treatment." Qualitative Health Research 29(8): 11991212.

Sánchez, Francisco J., Stefanie T. Greenberg, William Ming Liu, \& Eric Vilain. 2009. "Reported effects of masculine ideals on gay men." Psychology of men \& masculinity 10(1): 73-87. DOI.org/10.1037/a0013513

Saxonberg, Steven \& Dorota Szelewa. 2007. “The continuing legacy of the communist legacy? The development of family policies in Poland and the Czech Republic social politics." International Studies in Gender, State and Society 14(3): 351-379.

Scourfield, Jonathan. 2005. "Suicidal masculinities.” Sociological Research Online 10(2): 35-44. DOI.org/10.5153/sro.1057

Seamont, Morgan M. H. 2018. "Becoming “The Man I Want to Be": Transgender masculinity, embodiment, and sexuality.” Anthropology Graduate Theses \& Dissertations 85. Retrieved July 5, 2020 (https://scholar.colorado.edu/anth_gradetds/85).

Seaton, Cherisse L., Joan L. Bottorff, Margaret Jones-Bricker, John L. Oliffe, Damen DeLeenheer, \& Kerensa Medhurst. 2017. "Men's mental health promotion interventions: A scoping review.” American Journal of Men's Health 11(6): 1823-1837. DOI: $10.1177 / 1557988317728353$

Shiner, Michael, Jonathan Scourfield, Ben Fincham, \& Susanne Langer. 2009. "When things fall apart: Gender and suicide across the life-course." Social Science \& Medicine 69(5): 738-746. DOI: 10.1016/j.socscimed.2009.06.014.

Snell, Daniel M. \& James M. A. Turner. 2018. "Sex chromosome effects on male-female differences in mammals.” Current Biology 28(22): R1313-R1324. DOI:10.1016/j. cub.2018.09.018

Sobkowiak, Mariusz. 2011. „Przeciwdziałanie zachowaniom suicydalnym w pracy socjalnej." Gorzów Wielkopolski: Publikatorina.

Soman, Uthara. 2009. "Patriarchy: Theoretical postulates and empirical findings." Sociological Bulletin 58(2): 253-272. Retrieved February 7, 2021 (http://www.jstor.org/ stable/23620688).

Stack, Steven. 1983. "The effect of religious commitment on suicide: A cross-national analysis." Journal of Health and Social Behavior 24(4): 362-374.

Szwed, Anna. 2019. “Typy legitymizacji w wypowiedziach hierarchów Kościoła rzymskokatolickiego w Polsce na temat gender i praw reprodukcyjnych.” Studia Socjologiczne 3(234): 81-108.

Świder, Magdalena \& Mikołaj Winiewski, eds. 2017. Sytuacja społeczna osób LGBTA w Polsce. Raport za lata 2015-2016. Warszawa: Kampania Przeciw Homofobii.

Tsirigotis, Konstantinos, Wojciech Gruszczyński, \& Marta Tsirigotis-Maniecka. 2015. „Autodestruktywność pośrednia u osób homoseksualnych.” Psychiatria Polska 
49(3): 543-557.

Wacławik, Sylwia. 2011. „Homoseksualny oznacza chory? Stereotypowe powiązanie homo- i biseksualizmu z zaburzeniami psychicznymi na przykładzie wybranych filmów” Nowiny Lekarskie 80(5): 349-357.

VanderWeele, Tyler J., Shanshan Li, Alexander C. Tsai, et al. 2016. “Association between religious service attendance and lower suicide rates among US women.” JAMA Psychiatry 73(8): 845-851. DOI:10.1001/jamapsychiatry.2016.1243

Van Hal, Guido. 2015. "The true cost of the economic crisis on psychological well-being: A review.” Psychology research and behavior management 8: 17-25. DOI: 10.2147/PRBM.S44732

Wang, Yiyan. 2005. "Review of the book The Fragile Scholar: Power and Masculinity in Chinese Culture." China Review International 12(2): 554-557. DOI:10.1353/ cri.2006.0070

Zarzycka, Beata, Radosław Rybarski, \& Jacek Sliwak. 2017. “The relationship of religious comfort and struggle with anxiety and satisfaction with life in Roman Catholic Polish men: The moderating effect of sexual orientation." Journal of Religion and Health 56(6): 2162-2179. DOI: 10.1007/s10943-017-0388-y

Ziółkowska, Justyna. 2016. „Samobójstwo. Analiza narracji osób po próbach samobójczych [Suicide. An analysis of suicide attempters’ narratives]. Warszawa: PWN.

\section{BIOGRAPHICAL NOTES}

Jarosław R. Romaniuk, PhD, LISW-S, LICDC, is a researcher and educator. Currently he works as a fulltime lecturer at the Mandel School of Applied Social Sciences. From 2004 to 2015 he worked as a social worker at the Louis Stokes Cleveland Department of Veterans Affairs Medical Center. He also worked in the School of Medicine, Case Western Reserve University, as a neuroscientist. His experience at the VA has led him to participate in national VA committees and the National Association of Social Workers in Ohio. He was also involved locally, as a Board member of The Alcohol, Drug Addiction and Mental Health Services (ADAMHS) Board of Cuyahoga County (2010-2017).

Anna Kotlarska-Michalska, Professor at the Adam Mickiewicz University in Poznań. Head of the Department of Research on Social Problems and Social Work at the Faculty of Sociology in 2000-2020. Head of the specialization course Organization of Social Welfare. Co-organizer of undergraduate and graduate studies in the field of social work at AMU. President of the Board of the Polish Association of Social Work Schools in 2011-2019. Scientific achievements: over 220 works (mainly scientific articles) in the field of social work, family sociology, social policy, gerontology, sociology of social problems, deviation and social pathology. Author of several dozen publishing reviews in sociology and social work, several reviews in doctoral and postdoctoral dissertations. Reviewer in several scientific journals with a sociological profile. She is currently researching the causes of social insecurity and invisible social problems.

Kathleen J. Farkas, Ph.D. LISW-Supv. is an Associate Professor of Social Work at the Jack, Joseph and Morton Mandel School of Applied Social Sciences, Case Western Reserve University, Cleveland, Ohio, USA. She has extensive clinical and research experience in the areas of mental health and addictions assessment and treatment. Dr. Farkas has a long time interest in substance use issues among older 
adults and women, and her work has focused on addictions and mental health issues among those incarcerated in jails and prisons. Recently she has been involved in research, teaching, and publications related to animal assisted interventions in mental health and addictions. She is the chairperson of the Mandel School's direct practice faculty as well as the specialization faculty for substance use disorders and recovery.

OPEN ACCESS: This article is distributed under the terms of the Creative Commons Attribution Non-commercial License (CC BY-NC 4.0) which permits any non-commercial use, and reproduction in any medium, provided the original author(s) and source are credited.

ARTICLE HISTORY: Received 2020-09-15 / Accepted 2021-02-22 
